\section{What About Your Futures, Technology Assessment?}

\author{
An Essay on How to Take the Visions of \\ TA Seriously, Motivated by the PACITA \\ Conference $^{1}$
}

\author{
by Christoph Schneider, and Andreas \\ Lösch, Institute for Technology Assessment \\ and Systems Analysis (ITAS), Karlsruhe
}

The visions of TA itself receive hardly any attention, although the field is variously engaged in the contests of sociotechnical futures in the making. In this essay we show, however, that TA is full of implicit and explicit visions of the future and that it enacts different relationships to these visions and the role they play in innovation and transformation processes. We outline the three ideal types "observer of visions", "co-constructor of visions", and "visioneer" to designate different modes how TA is dealing with visions of the future - by others and by itself. These ideal types may help to (dis-)entangle the different implicit and explicit TA visions in current TA practices and may serve as an orientation to develop a "visioneering TA" which strategically takes part in contesting futures through promoting visions. The essay ends with suggestions for TA to engage more seriously with its futures.

What is the future of Technology Assessment (TA)? If you go and ask the field itself, you will find only few documents that envision futures of TA, although this remarkable young field of problem-oriented research has been trying since its inception to change how societies deal with technologies. Is that not an emphatic vision ${ }^{2}$ inscribed into the whole field? And is it not surprising that TA only seldom explicitly turns towards it? Recently the PACITA project published the TA Manifesto, a rare example of TA explicitly turning towards its own future. There you can read, amongst other visionary sentences, that "the global transforming power of technology ... has to be aligned with policymaking and democracy" (http://www.pacitaproject.eu/ ta-manifesto/). However, even without this manifesto the PACITA conference 2015 showed the recent growth of TA and implicitly pointed towards its future potentials. But what are these future potentials? The common answer during the conference was: to spread parliamentary TA further across Europe; the vision fostered by the PACITA project. A rather conservative vision though, envisioning more of the same. That there is not a greater number of different visions in contemporary TA points towards a blind spot in the field's envisioning: the lack of reflection by TA on its own visions and their effects. TA is full of implicit and explicit visions - by others and by TA - as we will show. And there needs to be more self-reflexivity and a conscious use of these visions and more diverse practices engaging with different TA-vision relationships, for which we outline three ideal types. This essay is motivated by the panel "Visions of Technology Assessment" at the PACITA conference and a call for more of such self-reflexivity of the visions of TA. The assumption is that a TA with a better self-understanding of its visions makes more successful use of them - something necessary in innovation landscapes full of contested visions and the practices pushing them.

There is some evidence that, compared to TA, technoscience and its dominant circles of research, politics, and business is often more successful in using visions. Since visions influence innovation processes, as we know from research in Science and Technology Studies (Brown et al. 2000; Borup et al. 2006; Adam/Groves 2007), technoscientists and the coalitions they build are often more influential on these processes. TA has been reacting to such technoscientific visions. From the civil use of nuclear technology via mobile phones to synthetic biology, visions of the future, hopes, and fears make the work of TA possible, and be it only by pointing towards problems or opportunities. For many years researchers have been arguing that the scrutiny of technoscientific visions and their effects should become a central task of TA (see Grunwald in this issue). But there are also visions in TA, although they have not been completely discovered yet. The need to address the visions of TA itself led us to organise the panel on the visions of TA. Judging from the heated debate that this set off on the conference's last day, the perspective on these 
visions is quite energising. The invited panelists Michael Nentwich, Institute of Technology Assessment in Austria, Laurent Bontoux, European Commission Joint Research Centre, and Armin Grunwald, Institute for Technology Assessment and Systems Analysis, Germany, started with brief kick-off statements and the audience later joined in the overall discussion. The session touched upon the initial PACITA motivation and the project's outcomes, creating visions for policy makers in stakeholder workshops at the European Commission, different historical ideals of TA, the PACITA manifesto, the role of visions in practices and changes of TA, sustainability, and "Responsible Research and Innovation" (RRI) as a likely new form of envisioning TA.

Visions of the future do not tell us exactly what the future will hold, but tell us a lot about the contexts in which they are produced, circulated, transformed, contested, or taken for granted - and they have practical effects there. As Armin Grunwald pointed out at the panel discussion, visions entail a great deal of values, conceptions of the world, images of a "good" or "bad" society, and understandings of time and change. We add that such visions also entail self-perceptions and positionings of their "authors" (which can also be research projects, organisations, social movements, etc.). Interestingly though, Grunwald also admitted that it was difficult to find explicit visions of TA in the field's history. In the beginning ideas of measuring and controlling technological change could be discovered. And much effort had been put by TA practitioners into participation and thus into fostering a vision of a participatory society. Visions are not confined, however, to explicit discursive statements, they can also be implicit in particular practices. This is central to this essay: even doing something in the present can point towards and promote particular futures. Thus the question will be: which vision of a "good society" is implicitly or explicitly being advocated by TA and which "good" TA practices does this involve. Inspired by the discussions during the session, we propose three ideal types (condensed and simplified models of a more blurred reality) of how the relationship of the visions of TA and TA practice can be conceived and what they tell about the futures of TA: observing, co-constructing, and visioneering visions. These ideal types may help to (dis-)entangle the different implicit and explicit TA visions in current TA practices and may serve as an orientation to develop a "visioneering TA".

\section{The observer of visions}

Probably this is the most common understanding of how TA is dealing with visions. TA seems to take the position of a neutral observer of visions to analyse and to deconstruct them by assessing their feasibility and desirability. Typically, this would be critical of technoscientific visions (indeed, many are reductionist and technocratic) and aim to enlighten public debates or decision making. In a way, this aims to open up the future again by challenging technoscientific visions and closures they might be causing. This neutral observer position is based on dominant views of "objective science" which is constitutive of scientific advice to policy and is institutionalised with parliamentary TA as a legitimisation for politics. This draws upon the political vision of the scientific enlightenment of representative democracy. For parliamentary TA this implicitly envisions a society which does not solely let technologists and markets determine what its technologies look like; instead democratic politics should have a leading say in this and therefore need unbiased advice. But if technologists and markets have the dominant influence on technological innovation, this perspective - taken seriously - is highly visionary.

Turning towards the visions of TA, one could also observe the visions TA entails to become more self-reflexive and reveal visions implicitly held. Yet, such neutral science would typically not envision a change of its arrangements since it positions itself as reacting or listening to external demands. Parliamentary TA is established in many countries of Western Europe (see Hennen/Nierling 2015). In such cases there need not be an active use of visions of TA that promotes it as something desirable for society. This looks different, however, in the many countries where there is no such institutionalisation of TA. Spreading it there does not only need projects like PACITA but also the concrete 
construction and use of visions to help creating imaginations of and support for what an institutionalisation of TA might look like and why this is beneficial. Thus, even envisioning parliamentary TA can be "activist" as Jan Staman, former director of the Rathenau Institute, pointed out at the PACITA session.

\section{The co-constructer of visions}

Co-construction shows that there is no isolation of innovations or technologies, they entail translations between and connections of different knowledges and actors. In a way, every TA work is a co-construction, the empirically open question, however, is to what extent TA contributed to constructing. Even the objective observation of visions aims at having an impact on visionary discourses, or at least on decisions based on them. The amount of construction, however, advances if TA engages in selecting and arranging visions. When scenarios are prepared for discussions at participatory events, video clips are made to highlight ethical aspects of a technology, or emerging technologies are recommended for further research, TA is no longer the observer of visions but rather an active modulator of them. In instances of "constructive TA" (Schot/Rip 1997), aiming at a direct influence on technological research and development, TA practice co-constructs particular conditions for envisioning technologies.

But what does co-construction imply for the visions of TA itself? Such co-constructive TA is better not defined in terms of its institutionalisation, e.g. as policy advice. The constructions can be very diverse, TA could "co-operate" with all kinds of actors and organisations and in turn envision a broad spectrum of its own futures. Implicitly, co-constructive TA envisions a society where TA practices are an important mediator, translator, and analyser of sociotechnical effects of new and envisioned technologies in inter- and transdisciplinary contexts. Explicitly, it is hard to find visions of TA here besides participatory TA. Historically, however, one can identify sustainability, during the PACITA session mentioned by Arnold Sauter, TAB, as a candidate for a vision in TA, as a particular co-construction of TA and the environmental movement. Many TA studies helped to operationalise and promote a perspective on ecological effects of technologies and a vision of a sustainable society. Thinking of such a broad co-construction, the question would be with which other social movements could TA set out to co-construct a vision of a "good society" which also entails a vision for good TA practice?

\section{The visioneer}

"Visioneering", the conscious and strategic production, distribution, and use of visions, is an important activity in innovation and transformation processes. The historian of technology W. Patrick McCray showed how technoscientists like Eric Drexler (early nanotechnology visionary) successfully created, mobilised, and promoted visions to push particular technologies and agendas. They did not only think of a future, but built coalitions and networks, e.g., with politicians, business leaders, researchers, and publics, which together "could mobilize, explore, and push the limits of the possible" (McCray 2012, p. 10). The philosopher Alfred Nordmann (2013) suggested that visioneering creates tunnel visions and is not simply done by individuals, but instead is a collective and historical activity and that even TA would do this. But from our point of view the question for TA is: Can this not be done with awareness for how the limits of the possible are changed? If TA wants to have a transformative impact on sociotechnical change, why should it refrain from building coalitions with the help of visions and does an intended influence not entail the narrowing down of options and imaginations? Why should it refrain from trying to make futures rather than only reflecting on them? Actually, there are instances when TA exactly does so.

Take the example of RRI: some participants claimed that here TA pushes the respective vision. Leaving the question open whether or not TA is the source of RRI, this is a grand vision that was visioneered into policy by many researchers familiar with or engaged in TA. And this has certainly opened up possibilities for changes in innovation practices as the discourse is spreading and some policies are in place. How will these possibilities unfold, what will become of RRI? One 
can, of course, analyse how responsibility takes shape in innovation processes (which is worthwhile). But if one rather engages in creating and shaping arrangements of responsible innovation, its vision "better innovations for a better society" (cf. Guston et al. 2014) is a good candidate to build coalitions and to spread knowledge about RRI and its desirability.

Looking back in history, many TA activities have been promoting alternatives to particular technology-centred visions. When showing that there are other and potentially more beneficial options to tackle problems, e.g. through social instead of technical innovation, does TA then not engage in visioneering? This indicates that TA operates within changing landscapes full of visioneering activities by others promoting and lobbying for their visions. The future is contested - and TA could engage in these struggles more energetically by way of visioneering to create, stabilise, and advance alternatives. It would have to face the question, however, how reflexive visioneering could be done without losing sight of complexity, uncertainty, and plurality. A TA that would consciously engage in visioneering would need to reflect on and probably change and adapt its own practices. What is being visioneered cannot be separated from how this is done.

\section{Visions and TA - where to go?}

Our interpretation of TA practices through the three ideal types showed that TA is making futures, but in a twofold sense. The way how TA is dealing with the visions of others is entangled with how it treats its own visions. The "observer of visions TA" is critical of techno-visions and keeps its own visions implicit. "Co-constructionist TA" modifies the visions of others and envisions itself as a mediator in a society which is becoming more participatory. "Visioneer TA" pushes particular visions and places them in the contested field of sociotechnical future-making. These ideal types point towards different TA-vision relationships and entail practical consequences for doing TA and for transforming it. These ideal types might mix in TA practice, they do not correspond with particular institutions, organisations, or persons. They are possibilities, attitudes, enactments of TA practice, a practice which is complex. We furthermore made the distinction between explicit and implicit visions of TA, the latter designating the futures that are advocated by TA through doing what it does in the present. Explicitly formulated visions of TA are rare and the recent PACITA manifesto curiously covers less than the (implicit) futures that the multiplicity of TA practices have on offer. TA would benefit from a broader spectrum of explicit visions entangled with its own practices.

Where should TA go with its visions? First, obviously, there is a need for self-reflexivity in TA concerning its visions. Many opportunities for research open up to reveal the implicit and explicit visions in different (historical) forms of TA practices and the way they create or constrain spaces of possibility. Yet, such self-reflexivity should also enter the mundane work of TA practitioners asking themselves: Which is the "good society" that my work is advocating? What aspects of social life do I want to strengthen and support, which do I consider as harmful? Second, this hints at the need for an attitude in TA which embraces the creativity and flux of the present, moving along with TA as a changing, historical, and societal project as it unfolds into an open future - a future which leaves room for visions in the present. Third, there is a need for strategies fostering and shaping futures. Especially co-constructionist and visioneering TA cannot be satisfied with identifying or imagining visions. Rather, they need to be used to advance particular futures in the making. For this, coalitions need to be built, knowledge needs to be spread and practice needs to be inventive. Fourth, there is a need for innovation of TA. Not that this is not happening. But if TA takes it serious that its own visions can have effects in innovation and transformation processes (which would be a first innovation), they might be used to foster innovation with TA and in TA. Visioneering, by now hardly recognised, would then become a much more important activity in TA, consciously followed and experimented with.

What if TA really turned into a capacity of European societies and not only of its parliaments? Do you have visions for the future of TA? Do you want to participate in visioneering TA? 
Why do you not start by writing your reactions to this essay as a reply to a blog-version of this text on http://www.openta.net/blog, as a next small step in visioneering TA into the future?

\section{Notes}

1) We would like to thank Knud Böhle for his detailed comments on this essay and for organising the PACITA panel with us, as did Arianna Ferrari whom we would also like to thank. And we thank our other colleagues of the new ITAS project on "visions as socio-epistemic practices" (see: http:// www.itas.kit.edu/english/projects_loes14_luv. php) for sharing their views on visions in the contemporary world.

2) We use the term vision in a wide sense for imaginaries of the future which have the normative imperative to realise the futures they imagine.

\section{References}

Adam, B.; Groves, C., 2007: Future Matters: Action, Knowledge, Ethics. Leiden

Borup, M.; Brown, N.; Konrad, K. et al., 2006: The Sociology of Expectations in Science and Technology. In: Technology Analysis \& Strategic Management 18/3-4 (2006), pp. 285-298

Brown, N.; Rappert, B.; Webster, A. (eds.), 2000: Contested Futures: A Sociology of Prospective Techno-Science. Farnham

Grunwald, A., 2015: Die hermeneutische Erweiterung der Technikfolgenabschätzung. In: Technikfolgenabschätzung - Theorie und Praxis (TATuP) 24/2 (2015), pp. 65-69

Guston, D.H.; Fisher, E.; Grunwald, A. et al., 2014: Responsible Innovation: Motivations for a New Journal. In: Journal of Responsible Innovation 1/1 (2014), pp. 1-8

Hennen, L.; Nierling, L. (eds.), 2015: TA as an Institutionalized Practice - Recent National Developments and Challenges. Thematic Focus. In: Technikfolgenabschätzung - Theorie und Praxis 24/1 (2015), pp. 3-74 McCray, W.P., 2012: The Visioneers: How a Group of Elite Scientists Pursued Space Colonies, Nanotechnologies, and a Limitless Future. Princeton

Nordmann, A., 2013: Visioneering Assessment: On the Construction of Tunnel Visions for Technovisionary Research and Policy. In: Science, Technology \& Innovation Studies 9/2 (2013), pp. 89-94
Schot, J.; Rip, A., 1997: The Past and Future of Constructive Technology Assessment. In: Technological Forecasting and Social Change 54/2-3 (1997), pp. 251-268

\section{Contact}

Christoph Schneider, M.A.

Tel.: +49 721 608-24792

Email: christoph.schneider3@kit.edu

PD Dr. Andreas Lösch

Phone: +49 721 608-22505

Email: andreas.loesch@kit.edu

Institute for Technology Assessment and Systems Analysis (ITAS)

Karlsruhe Institute for Technology (KIT)

Karlstraße 11, 76133 Karlsruhe 